
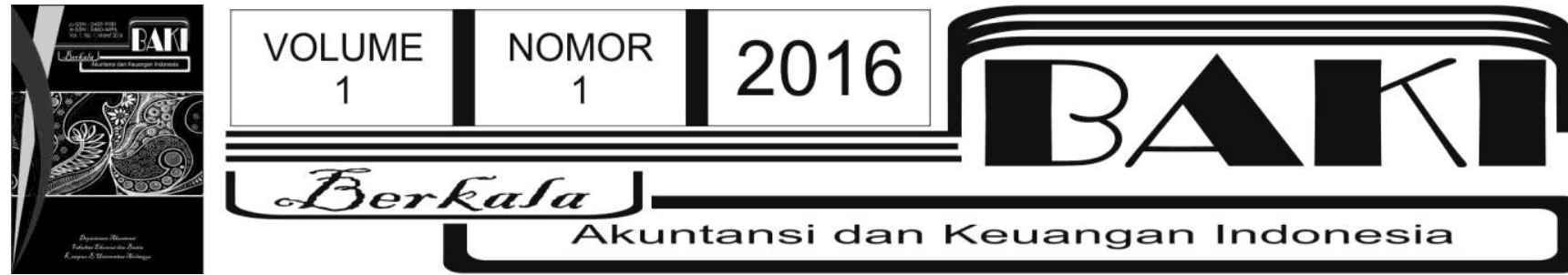

Berkata

Akuntansi dan Keuangan Indonesia

\title{
Evaluasi Kendala Ekstensifikasi Wajib Pajak Usaha Mikro Kecil dan Menengah di Kecamatan Gubeng Kota Surabaya Sesudah Pemberlakuan Peraturan Pemerintah Nomor 46 Tahun 2013
}

\author{
Lintang Nahdya Putri, Made Dudy Satyawan* \\ *Universitas Negeri Surabaya \\ *dude05_jr@yahoo.com
}

I NFO ARTIKEL

Histori Artikel:

Tanggal Masuk 29 September 2015

Tanggal Diterima 23 Februari 2016

Tersedia Online 31 Maret 2016

Kata Kunci:

Evaluasi;

Kendala;

Kegiatan Ekstensifikasi;

Faktor-Faktor UMKM

\begin{abstract}
A BSTRAK
Penelitian ini bertujuan untuk mengevaluasi kegiatan ekstensifikasi sesudah pemberlakuan PP Nomor 46 Tahun 2013 di KPP Pratama, Gubeng Kota Surabaya. Terdapat tiga cara melakukan kegiatan ekstensifikasi. Cara-caranya adalah mengunjungi lokasi UMKM (Usaha Mikro, Kecil, Menengah), pendataan pemilik dari UMKM, dan memberikan surat himbauan pendaftaran. Teknik pengumpulan data menggunakan wawancara dan dokumentasi. Kemudian, data dianalisis dengan menggunakan triangulasi sumber dan teori. Hasil penelitian ini menyimpulkan bahwa terdapat faktor-faktor yang menjadi kendala dari kegiatan ekstensifikasi di KPP Pratama Gubeng Kota Surabaya yaitu kurang aktif dalam melakukan kegiatan ekstensifikasi, pemilik UKM melakukan penghindaran ketika kegiatan ekstensifikasi berlangsung, dan pemilik UMKM kurang memiliki pemahaman tentang pajak.
\end{abstract}

\section{Pendahuluan}

\subsection{Latar Belakang}

Pajak di Indonesia saat ini masih merupakan sumber utama dari penerimaan negara. Pada Anggaran Pendapatan dan Belanja Negara (APBN) tahun 2014 yang telah disahkan pemerintah, pendapatan negara ditargetkan sebesar Rp 1.667,1 Triliun. Kontribusipenerimaan dalam bentuk pajak adalah sebesar $66,50 \%$. Kontribusi penerimaan pajak tersebut merupakan jumlah terbesar dalam pendapatan negara dibandingkan jenis-jenis penerimaan negara lainnya. Strategiperpajakanyang digunakan untuk mewujudkan target penerimaan pajak, Direktorat Jenderal Pajak melakukan upaya intensifikasi dan ekstensfikasi pajak. Soemitro (2000) menjelaskan intensifikasi pajak adalah peningkatan intensitas pungutan terhadap suatu subjek dan objek pajak yang potensial. Sedangkan, ekstensifikasi pajak, yaitu upaya memperluas subjek dan objek pajak serta penyesuaian tarif pajak. 
Salah satu upaya ekstensifikasi pajak saat ini adalah dengan membidik para pelaku/pengusaha UMKM (Usaha Mikro Kecil dan Menengah) dengan peredaran bruto dibawah Rp. 4.8 milyar. Badan Pusat Statistik mencatat pada tahun 2011 dan 2012 kontribusi UMKM untuk PDB (Produk Domestik Bruto) nasional cukup besar, yaitu diatas 50\%. Tingginya kontribusi UMKM pada PDB nasional juga diikuti dengan tingginya kontribusi UMKM kota-kota besar pada PDRB (Produk Domestik Regional Bruto).

Tabel 1

Kontribusi UMKM pada PDRB (Produk Domestik Regional Bruto) Ibukota Provinsi di Pulau Jawa Tahun 2011-2012

\begin{tabular}{|l|c|c|}
\hline \multirow{2}{*}{ Nama Kota } & \multicolumn{2}{c|}{ Kontribusi UMKM pada PDRB (\%) } \\
\cline { 2 - 3 } & 2011 & 2012 \\
\hline DKI Jakarta & $20,80 \%$ & $20,70 \%$ \\
\hline Kota Bandung & $41,20 \%$ & $41,70 \%$ \\
\hline Kota Semarang & $28,01 \%$ & $28,40 \%$ \\
\hline Kota Yogyakarta & $19,80 \%$ & $20,08 \%$ \\
\hline Kota Surabaya & $43,90 \%$ & $44,46 \%$ \\
\hline
\end{tabular}

Sumber: Badan Pusat Statistik (2014)

Dari Tabel 1 dapat dilihat bahwa Kota Surabaya memiliki UMKM dengan kontribusi tertinggi untuk PDRB (Produk Domestik Regional Bruto), bila dibandingkan dengan kota-kotapada provinsi lainnya di Pulau Jawa. Hal itu juga menandakan jumlah UMKM di Kota Surabaya lebih banyak daripada kota-kota lainnya. Seperti yang telah tercatat di Indipreneur Telkom Indonesia Cabang Surabaya, pada awal tahun 2015 UMKM di Kota Surabaya telah mencapai 22.759 unit yang tersebar di berbagai kecamatan.

Tabel 2

Jumlah UMKM pada 10 Kecamatan di Kota Surabaya dengan Jumlah UMKM Terbanyak

\begin{tabular}{|l|l|}
\hline Nama Kecamatan & Jumlah UMKM \\
\hline Kecamatan Tegalsari & 1.126 \\
\hline Kecamatan Genteng & 1.254 \\
\hline Kecamatan Pabean Cantikan & 921 \\
\hline Kecamatan Gunung Anyar & 596 \\
\hline Kecamatan Sukolilo & 630 \\
\hline Kecamatan Gubeng & 1.566 \\
\hline Kecamatan Sukomanunggal & 681 \\
\hline Kecamatan Wonokromo & 952 \\
\hline Kecamatan Tambaksari & 1.136 \\
\hline Kecamatan Bubutan & 1.063 \\
\hline
\end{tabular}

Sumber:http://www.smartbisnis.co.id/direktoriukm/cari?city=244\&Dir_sort=district.desc\&D ir_page $=1425$ (Diakses 16 Maret 2015)

Tabel 2 menunjukkan bahwa Kecamatan Gubeng memiliki jumlah UMKM terbanyak di Kota Surabaya. Sebanyak 1.566 UMKM beroperasi di Kecamatan Gubeng terbagi atas beberapa jenis usaha, seperti home industry, fotocopy dan rental, bengkel otomotif, usaha kuliner, dan lainnya.Namun, 1.566 UMKM yang tersebar di Kecamatan Gubeng tersebut belum seluruhnya terdaftar dan memenuhi kriteria sebagai wajib pajak UMKM.

Selama ini dalam sistem pengenaan pajak terutangnya, pelaku UMKM di Kecamatan Gubeng Surabaya menggunakan Norma Perhitungan Penghasilan Netto (NPPN). Ketidaksederhanaan dalam proses perhitungan pajak menjadi kendala penerapan Norma Perhitungan Penghasilan Netto. 
Kendala tersebut ditandai dengan kecenderungan terjadinya penurunan jumlah wajib pajak pada tiap tahunnya.

Tabel 3

Jumlah Wajib Pajak Baru dengan Norma Perhitungan Penghasilan Netto KPP Pratama Surabaya Gubeng Tahun 2010-2012

\begin{tabular}{|c|c|}
\hline Tahun & Jumlah WP Baru \\
\hline 2010 & 735 \\
\hline 2011 & 702 \\
\hline 2012 & 676 \\
\hline
\end{tabular}

Sumber: KPP Pratama Surabaya Gubeng. 2015. Hasil Wawancara tentang

"Kegiatan ekstensifikasi PP 46 Tahun 2013 untuk UMKM Kecamatan Gubeng"

Ketidaksederhanaan dalam penghitungan pajak berdasarkan metode Norma Perhitungan Penghasilan Netto yang dialami oleh UMKM dikarenakan sebagian besar pemilik UMKM memiliki kompetensi pengetahuan yang minim dan tingkat kesadaran yang rendah terhadap pajak. Kuncahyo (2013) menjelaskan sebagian besar UMKM tumbuh secara tradisional dan biasanya merupakan usaha keluarga yang turun temurun. Pemilik UMKM lebih disibukkan dengan pengembangan usahanya dan tidak ada waktu untuk membenahi sistem administrasinya. Selain itu untuk mendapatkan karyawan yang memahami pencatatan akuntansi dan perpajakan juga membutuhkan biaya yang tidak sedikit.

Untuk menanggapi problematika UMKM tersebut, maka dikeluarkanlah Peraturan Pemerintah Nomor 46 Tahun 2013 tentang Pajak Penghasilan atas Penghasilan dari Usaha yang Diterima atau Diperoleh Wajib Pajak yang Memiliki Peredaran Bruto Tertentu. Tujuan dari peraturan pajak ini adalah untuk memberikan kemudahan Wajib Pajak melakukan penghitungan, penyetoran, dan pelaporan pajak penghasilan yang terutang. Besarnya tarif pajak penghasilan yang dikenakan adalah pajak final sebesar $1 \%$. Tarif pajak tersebut dikenakan terhadap penghasilan bruto dari usaha dalam 1 (satu) tahun dari Tahun Pajak.

Setelah diberlakukannya PP 46 Tahun 2013 per tanggal 1 Juli 2013, jumlah WP Badan baru KPP Pratama Surabaya Gubeng tetap mengalami penurunan. Jumlah WP Badan baru sesudah pemberlakuan PP 46 Tahun 2013 dapat dilihat sebagai berikut:

\section{Tabel 4}

Jumlah Wajib Pajak Baru dengan Tarif 1\% Menurut PP 46 Tahun 2013 KPP Pratama Surabaya Gubeng Tahun 2013-2014

\begin{tabular}{|c|c|}
\hline Tahun & Jumlah WP Baru \\
\hline 2013 & 655 \\
\hline 2014 & 624 \\
\hline Sumber: KPP Pratama Surabaya Gubeng. 2015. Hasil Wawancara tentang \\
"Kegiatan ekstensifikasi PP 46 Tahun 2013 untuk UMKM Kecamatan Gubeng"
\end{tabular}

Penurunan jumlah WP baru berkaitan dengan kegiatan ekstensifikasi yang selama ini dilakukan oleh KPP Pratama Surabaya Gubeng. Kegiatan ekstensifikasi PP 46 Tahun 2013 dilaksanakan berdasarkan Peraturan DJP No. 35 Tahun 2013 tentang Tata Cara Ekstensifikasi. Menurut Denok Hanurti, A.Md., staf Seksi Ekstensifikasi dan Penyuluhan KPP Pratama Surabaya Gubeng, kegiatan 
ekstensifikasi dilakukan dengan tiga cara, yakni pendatangan langsung ke tempat UMKM, melalui pemberi kerja, dan surat himbauan, yang dikirimkan kepada UMKM, jika dalam waktu 14 (empat belas) hari tidak ada tanggapan dari UMKM tentang kegiatan ekstensifikasi awal.

Dalam melaksanakan kegiatan ekstensifikasi KPP Pratama Surabaya Gubeng banyak mengalami kendala, tetapi sayangnya kendala yang dihadapi tidak diselesaikan dengan solusi yang baik. Denok Hanurti, A.Md. mengatakan bahwa kendala yang dihadapi antara lain, ketidakjelasan alamat UMKM yang akan didatangi. Selain itu, pemilik UMKM terkadang juga tidak ingin ditemui oleh petugas ekstensifikasi. Sedangkan, kendala untuk surat himbauan, yaitu sering mengalami kempos alias kembali ke pos karena alamat tujuan yang tidak dikenali. Kendala-kendala tersebut tidak ditindaklanjuti dengan baik oleh KPP Pratama Surabaya Gubeng. Mereka hanya membiarkan saja kendala-kendala tersebut, kemudian mereka beralih fokus kepada calon wajib pajak yang lain

Oleh karena itu, untuk melihat faktor-faktor yang menjadi kendala dalam kegiatan ekstensifikasi wajib pajak UMKM, diperlukan penuangan dalam penelitian yang berjudul "EVALUASI PROGRAM EKSTENSIFIKASI WAJIB PAJAK PENGHASILAN USAHA MIKRO KECIL DAN MENENGAH KECAMATAN GUBENG KOTA SURABAYA SESUDAH PEMBERLAKUAN PERATURAN PEMERINTAH NOMOR 46 TAHUN 2013".

Berdasarkan uraian latar belakang di atas, maka rumusan masalah yang dikembangkan adalah mengenai faktor-faktor apakah yang menjadi kendala dari upaya ekstensifikasi pajak UMKM di KPP Pratama Surabaya Gubeng sesudah pemberlakuan Peraturan Pemerintah Nomor 46 Tahun 2013 ?

Tujuan dari penelitian ini adalah untuk mengetahui faktor-faktor yang menjadi kendala upaya ekstensifikasi pajak UMKM KPP Pratama Surabaya Gubeng sesudah pemberlakuan Peraturan Pemerintah Nomor 46 Tahun 2013.

\section{Tinjauan Pustaka}

\subsection{Teori - Teori yang Digunakan}

\subsubsection{Teori Kebijakan Publik}

Terdapat beberapa klasifikasi definisi tentang kebijakan publik, salah satunya diungkapkan oleh Chandler dan Plano (1988). Menurut mereka, kebijakan publik adalah pemanfaatan yang strategis terhadap sumberdaya yang ada untuk memecahkan masalah-masalah publik atau pemerintah. Kebijakan publik merupakan suatu bentuk intervensi yang dilakukan secara terus menerus oleh pemerintah demi kepentingan kelompok yang kurang beruntung dalam masyarakat agar mereka dapat hidup, dan ikut berpartisipasi dalam pembangunan secara luas. Dalam hal ini pemerintah mendayagunakan berbagai instrumen yang dimiliki untuk mengatasi persoalan publik.

\subsubsection{Usaha Mikro, Kecil, dan Menengah (UMKM)}

Menurut Peraturan Pemerintah Nomor 46 Tahun 2013, Wajib Pajak UMKM yang termasuk di dalamnya didasarkan pada penghasilan dari usaha. UMKM dikategorikan menerima penghasilan dari 
usaha, tidak termasuk penghasilan dari jasa sehubungan dengan pekerjaan bebas, dengan peredaran bruto tidak melebihi Rp 4.800.000.000 (empat miliar delapan ratus juta rupiah) dalam 1 (satu) Tahun Pajak.

\subsubsection{Pengertian Pajak}

Pajak memiliki beberapa pengertian yang didefinisikan oleh beberapa ahli. Definisi pajak menurut masing-masih ahli, sebagai berikut :

1. Menurut Francais dalam Suandy (2011), termuat dalam buku Leroy Beaulieu (1906) yang berjudul Traite de la Science des Finance, mengatakan bahwa pajak adalah bantuan, baik secara langsung mupun tidak yang dipaksakan oleh kekuasaan publik dari penduduk atau dari barang, untuk menutup belanja pemerintah

2. Prof. Dr. Rochmat Soemitro, SH., dalam Suandy (2011), dalam bukunya Dasar-dasar Hukum Pajak dan Pajak pendapatan, mengatakan bahwa Pajak adalah iuran rakyat kepada kas negara berdasarkan undang-undang (yang) dapat dipaksakan dengan tidak mendapat jasa imbal (kontraprestasi), yang langsung dapat ditunjukkan dan yang digunakan untuk membayar pengeluaran umum. Dengan penjelasan, "dapat dipaksakan" artinya bila utang pajak tidak dibayar, utang itu dapat ditagih dengan menggunakan kekerasan, seperti Surat Paksa dan Sita, dan juga penyanderaan; terhadap pembayaran pajak, tidak dapat ditunjukkan jasa timbal-balik tertentu, seperti halnya dengan retribusi.

\subsubsection{Asas Pemungutan Pajak}

Menurut Adam Smith dalam Suandy (2011: 23) menyatakan bahwa terdapat empat asas perpajakan yang dikenal dengan nama "Four Maxims of Taxation", yaitu Asas Keadilan (Equality), Asas Kepastian (Certainty), Asas Kesederhanaan (Conveniency), dan Asas Ekonomi (Economy).

1. Asas Keadilan (Equity)

Pemungutan pajak harus dilaksanakan secara adil sesuai dengan tujuan hukum pada umumnya. Asas ini harus selalu dipegang teguh, baik dalam perundang-perundangan, maupun dalam prakteknya sehari-hari.

2. Asas Kepastian (Certainty)

Pemungutan pajak harus ada jaminan kepastian hukum, baik yang menyangkut kepentingan negara, maupun bagi wajib pajak. Penetapan pajak yang dibebankan kepada wajib pajak tidak boleh sewenang-wenang. Kepastian ini menjamin setiap orang untuk tidak ragu-ragu untuk menjalankan kewajiban membayar pajak karena segala sesuatu sudah jelas sesuai dengan undang-undang. 


\section{Asas Kesederhanaan (Convenience)}

Ada situasi yang harus dipertimbangkan dalam pembuatan undang-undang, yaitu kapan waktu yang tepat harus bayar pajak oleh Wajib Pajak. Berdasarkan asas ini, pembayaran pajak harus seuai dengan pada keadaan Wajib Pajak, sehingga memudahkan Wajib Pajak.

4. Asas Efisiensi (Eficiency)

Dalam melakukan pemungutan pajak harus selalu melihat apakah pajak yang ditetapkan sesuai dengan apa yang di dapat oleh Wajib Pajak. Berdasarkan asas ini dapat dilihat dari dua sisi, yaitu sisi fiscus, dikatakan efisien apabila biaya pemungutan pajak yang dilakukan di kantor pajak lebih kecil dari jumlah pajak yang berhasil dikumpulkan. Di sisi wajib pajak dikatakan efisien, jika biaya yang harus dikeluarkan oleh wajib pajak seminimal mungkin.

\subsubsection{Hambatan - Hambatan Pemungutan Pajak}

Mardiasmo (2009: 8) mengelompokkan hambatan terhadap pemungutan pajak menjadi perlawanan pasif dan perlawanan aktif.

1. Perlawanan pasif.

Perlawanan pasif muncul akibat masyarakat enggan membayar pajak, yang dapat disebabkan kurangnya perkembangan intelektual dan moral masyarakat tentang seluk-beluk pajak, sistem perpajakan yang (mungkin) sulit dipahami masyarakat, serta sistem kontrol pajak yang tidak dapat dilakukan atau dilaksanakan dengan baik

2. Perlawanan aktif.

Tujuan perlawanan aktif, yaitu menghindari pajak secara terang-terangan dengan semua usaha dan perbuatan yang secara langsung ditujuan kepada fiscus. Bentuk perlawanan aktif ada dua, yaitu :

a) Tax avoidance dengan usaha meringankan beban pajak dengan tidak melanggar undangundang.

b) Tax evasion meringankan beban pajak dengan cara melanggar undang-undang (menggelapkan pajak).

\subsubsection{Peraturan Pemerintah Nomor 46 Tahun 2013}

Peraturan Pemerintah Nomor 46 Tahun 2013 tentang penghasilan dari usaha yang diterima atau diperoleh Wajib Pajak yang memiliki peredaran bruto tertentu, dikenai Pajak Penghasilan yang bersifat final. Peraturan Pemerintah Nomor 46 Tahun 2013 mulai berlaku pada tanggal 1 Juli 2013. Tujuan pengaturan ini adalah untuk memberikan kemudahan kepada Wajib Pajak yang menerima atau memperoleh penghasilan dari usaha yang memiliki peredaran bruto tertentu, untuk melakukan penghitungan, penyetoran, dan pelaporan pajak penghasilan yang terutang. Wajib Pajak yang memiliki peredaran bruto tertentu adalah Wajib Pajak yang memenuhi kriteria sebagai berikut :

1) Wajib Pajak orang pribadi atau Wajib Pajak badan tidak termasuk bentuk usaha tetap, dan 
2) Menerima penghasilan dari usaha, tidak termasuk penghasilan dari jasa sehubungan dengan pekerjaan bebas, dengan peredaran bruto tidak melebihi Rp 4.800.000.000,00 (Empat miliar delapan ratus juta rupiah) dalam 1 (satu) Tahun Pajak.

Tidak termasuk Wajib Pajak orang pribadi adalah Wajib Pajak orang pribadi yang melakukan kegiatan usaha perdagangan dan/atau jasa yang dalam usahanya:

1) Menggunakan sarana atau prasarana yang dapat dibongkar pasang, baik yang menetap maupun tidak menetap, dan

2) Menggunakan sebagian atau seluruh tempat untuk kepentingan umum yang tidak diperuntukkan bagi tempat usaha atau berjalan.

Tidak termasuk Wajib Pajak badan adalah:

1) Wajib Pajak badan yang beroperasi secara komersial

2) Wajib Pajak badan yang dalam jangka waktu 1 (satu) tahun setelah beroperasi secara komersial memperoleh peredaran bruto melebihi Rp 4.800.000.000,00 (Empat miliar delapan ratus juta rupiah).

Besarnya tarif Pajak Penghasilan yang bersifat final adalah 1\% (satu persen). Pengenaan Pajak Penghasilan didasarkan pada peredaran bruto dari usaha dalam 1 (satu) tahun dari Tahun Pajak terakhir sebelum Tahun Pajak yang bersangkutan. Dasar pengenaan pajak yang digunakan untuk menghitung Pajak Penghasilan yang bersifat final adalah jumlah peredaran bruto setiap bulan.

\subsection{Penelitian Terdahulu}

Kharisma (2014) memaparkan tentang pengaruh pelaksanaan Peraturan Pemerintah Nomor 46 Tahun 2013 terhadap kelangsungan UMKM. Penelitian yuridis-normatif tersebut menarik sebuah kesimpulan bahwa peraturan pemerintah tersebut masih belum bisa berjalan lancar sebagaimana mestinya. Peneliti menerangkan alasan dikarenakan kurangnya sosialisasi kepada pemilik UMKM. Sisi lain yang dikupas dalam penelitian ini adalah adanya pro dan kontra yang menaungi penerbitan peraturan pemerintah tersebut. Menurut peneliti, dampak positif yang dirasakan pemilik UMKM, yaitu adanya kesederhanaan dalam menghitung, menyetor, dan melaporkan pajak terutangnya. Selain itu, pemilik UMKM juga diarahkan untuk menjadi usaha formal akibat adanya NPWP yang melekat pada badan usaha. Namun, terdapat dampak negatif juga, yaitu pemilik UMKM merasakan pemungutan pajak final 1 persen tersebut tidak mencerminkan kemampuan membayar pajak masing-masing Wajib Pajak. Sukmawati (2014) dari hasil penelitiannya tentang efektifitas pelaksanaan ekstensifikasi wajib pajak menemukan bahwa melalui aktivitas pengamatan, pencarian data potensi perpajakan, sosialisasi peraturan terbaru, edukasi dan penyuluhan kepada wajib pajak baru program ekstensifikasi tersebut berhasil meningkatkan jumlah wajib pajak terdaftar di KPP Pratama Malang Utara.

Purbaningrum (2014) hasil penelitiannya pada KPP Pratama Blitar menemukan bahwa peran aktif petugas pajak dalam memberikan penyuluhan berupa seminar dan kelas pajak, pembagian 
leafet, sosialisasi melalui radio dan surat kabar lokal, serta penyediaan media informasi di kantor pajak mampu secara efektif meningkatkan kepatuhan wajib pajak yang terkategori PP No. 46 Tahun 2013. Simpulan hasil penelitian yang menyatakan perihal berbeda dengan peneliti sebelumnya, Resyniar dan Puspitasari (2014) menyatakan bahwa mayoritas pelaku UMKM di Wilayah Kota Malang tidak setuju penerapan PP 46/2013 karena belum mampu meng-edukasi masyarakat untuk transparan membayar pajak dan sosialisasi peraturannya dirasa kurang maksimal, akan tetapi informan setuju pada kemudahan dan kesederhanaan pembayaran pajak pelaku UMKM. Sedangkan Peptasari (2015) hasil penelitiannya menunjukkan setelah penerapan PP No.46 Tahun 2013 pertumbuhan jumlah wajib pajak mengalami penurunan sebesar $0,8 \%$.

\section{Metodologi Penelitian}

\subsection{Jenis Penelitian}

Pendekatan penelitian yang dilakukan dalam penelitian ini adalah metode kualitatif dengan pendekatan fenomenologi. Alasan dipilihnya metode kualitatif dalam penelitian ini karena penelitian ini berusaha memahami fenomena ekstensifikasi wajib pajak UMKM sesudah pemberlakuan Peraturan Pemerintah No. 46 Tahun 2013. Penelitian dilakukan secara holistik (utuh), mengupas tuntas secara habis tentang upaya ekstensifikasi mulai dari KPP Pratama Surabaya Gubeng, Disperdagin Kota Surabaya, pelaku UMKM, hingga praktisi pendidikan. Selain itu, penelitian ini juga menggunakan deskripsi dalam bentuk kata-kata, dimana hal itu merupakan ciri utama penelitian kualitatif. Sedangkan, alasan peneliti memilih pendekatan fenomenologi karena peneliti juga mengungkapkan upaya ekstensifikasi dari interpretasi pemilik UMKM sebagai wajib pajak. Interpretasi tersebut diartikan peneliti sebagai wujud kepatuhan pemilik UMKM untuk membayar pajak.

\subsection{Sumber dan Tehnik Pengumpulan Data}

Pemilihan informan pada penelitian dilakukan dengan cara menentukan informan kunci terlebih dahulu. Dalam penelitian ini, peneliti menentukan pemilihan informan kunci secara purposive. Pemilihan secara purposive, artinya informan dipilih berdasarkan pertimbangan penelitian subjektif dari peneliti, jadi dalam hal ini peneliti menentukan sendiri responden yang diinginkan. Peneliti menentukan tiga informan kunci, yaitu KPP Pratama Surabaya Gubeng, pemilik UMKM di Kecamatan Gubeng yang tersebar di 6 (enam) kelurahan, dan praktisi akademis

Pelaksanaan penelitian dan pengambilan data dilakukan pada bulan April sampai dengan Mei 2015. Teknik pengumpulan data dalam penelitian ini menggunakan wawancara semi terstruktur dengan para informan kunci yang menghasilkan data primer. Selain itu, dokumentasi juga digunakan dalam penelitian ini dengan sifat dokumen resmi internal. Moleong (2014) mengatakan dokumen internal berupa memo, pengumuman, instruksi, aturan suatu lembaga yang digunakan dalam kalangan sendiri. Dokumentasi dilakukan terhadap data-data dari Kantor Pelayanan Pajak (KPP) Pratama Gubeng Surabaya yang berupa laporan target dan realisasi bidang pendapatan dari pajak 
UMKM, dokumentasi sosialisasi Peraturan Pemerintan Nomor 46 Tahun 2013, serta data-data lainnya yang berkenaan dengan pajak UMKM.

\subsection{Metode Keabsahan dan Analisis Data}

Jenis triangulasi yang diterapkan dalam penelitian adalah triangulasi dengan sumber. Pada penelitian ini triangulasi dengan sumber dilakukan dengan jalan membandingkan data hasil wawancara pemilik UMKM dengan hasil dokumentasi dari pajak UMKM di KPP Pratama Gubeng Surabaya. Selanjutnya, teknik analisis yang digunakan adalah teknik analisis kualitatif yang disajikan dalam pembahasan berupa pengembangan konsep, mengkaji data yang didapat, dan analisis kesimpulan.

\section{Pembahasan}

Hasil wawancara dari 3 (tiga) informan kunci telah dilakukan triangulasi data untuk menemukan menemukan poin-poin penting yang menjadi kendala kegiatan ekstensifikasi PP 46 Tahun 2013 yang dilakukan KPP Pratama Surabaya Gubeng. Triangulasi dilakukan dengan melakukan cross check antar ketiga informan, kemudian ditemukan dengan teori yang relevan. Kendala-kendala yang melatarbelakangi kegiatan ekstensifikasi wajib pajak UMKM Kecamatan Gubeng Kota Surabaya sesudah pemberlakuan PP 46 Tahun 2013, meliputi:

\subsection{Kegiatan Ekstensifikasi PP 46 Tahun 2013 KPP Pratama Surabaya Gubeng}

Metode penjaringan calon wajib pajak yang tepat merupakan poin penting dalam sebuah kegiatan ekstensifikasi. Diperlukan tingkat keaktifan yang tinggi dari petugas ekstensifikasi KPP Pratama. Namun sayangnya, kegiatan ekstensifikasi yang telah terlaksana selama ini mengindikasikan bahwa petugas ekstensifikasi KPP Pratama Surabaya Gubeng belum cukup aktif

Denok Hanurti, A.Md., sebagai salah satu staff Seksi Ekstensifikasi dan Penyuluhan KPP Pratama Surabaya Gubeng mengenai pertanyaan "Bagaimana metode ekstensifikasi PP 46 Tahun 2013 yang dilakukan selama ini”. la mengatakan:

"Kalau untuk PP 46 Tahun 2013 selama ini kita kegiatan ekstennya selain datang ke tempat UMKM langsung, datang ke tempat pemberi kerja, surat himbauan, kita juga memasang banner ajakan PP 46 Tahun 2013 di halaman KPP kapan hari. Terus juga, kita nyebarin brosur-brosur gitu di depan pintu masuk atau nggak ya di depan gerbang buat yang lewat depan KPP”.

Kegiatan pemasangan banner dan penyebaran brosur tersebut sepertinya sangat disayangkan calon wajib pajak UMKM yang tidak tahu-menahu tentang PP 46 Tahun 2013. Seperti yang dikatakan oleh Koes Waluyo, pemilik Depot Pecel Madiun di Jalan Pucang Jajar Tengah, sebagai informan UMKM WP. Beliau berkata,

"Sosialisasinya belum cukup jelas gitu Mbak, peraturan pajaknya apa, tarifnya berapa juga belum jelas. Pajaknya masih kondisional seperti itu, masih berubah-ubah. Kita kan juga 
bingung. Petugas pajak juga nggak keliatan buat datang ke daerah sini buat sekedar njelasin gimana-gimananya peraturan itu".

Hal senada juga diungkapkan oleh informan UMKM non-WP fotocopy Hidayah yang dikelola oleh Agus Sujarwanto. Usaha fotocopy yang terletak di Jalan Karang Menjangan 50 ini mengatakan,

"Usaha kecil seperti fotocopyan gini belum ada pajak yang dikenakan. Tempat fotocopy ini saja juga masih sewa, jadi menurut saya kalau ada pajak untuk usaha kecil sepertinya justru memberatkan. Kalau memang usaha kecil sudah ada peraturan pajaknya berarti saya belum tahu karena memang belum ada orang pajak yang kesini".

Selanjutnya, peneliti berusaha mengajukan pertanyaan kembali kepada Seksi Ekstensifikasi dan Penyuluhan KPP Pratama Surabaya Gubeng mengenai pertanyaan "Bagaimana upaya KPP dalam mengatasi kendala yang terjadi ketika kegiatan ekstensifikasi berlangsung?". Denok Hanurti, A.Md. menjawab:

"Untuk solusi yang kita lakukan selama ini untuk ketiga metode ekstensifikasi ya kita biarkan saja. Kita juga agak bingung, masa ya kita mau maksa pemilik UMKMnya buat daftar jadi wajib pajak. Jadi ya akhirnya kita biarkan saja. Yang penting kita sudah melaksanakan kegiatan ekstensifikasi".

Untuk memastikan jawaban-jawaban sebelumnya, peneliti melakukan cross-check kepada praktisi akademis selaku pihak kompeten di bidang perpajakan. Pak Okta, dosen pengampu mata kuliah perpajakan FEB Unair memberikan keterangan sebagai berikut:

"Menurut saya sih, kegiatan ekstensifikasi PP 46 Tahun 2013 yang dilakukan KPP Pratama sudah baik. Namun menurut saya, masih banyak praktek ekstensifikasinya yang perlu ditindak lanjuti. Seperti sosialisasi ya. Saya kadang tidak merasakan adanya sosialisasi dari petugas KPP sendiri”.

Kemudian, peneliti menanyakan kepada seksi ekstensifikasi dan penyuluhan KPP Pratama Surabaya Gubeng, Denok Hanurti, A.Md. "Adakah strategi yang lebih efektif dalam melaksanakan kegiatan ekstensifikasi?". Dia menjawab, efektif".

"Menurut kami, metode ekstensifikasi PP 46 Tahun 2013 selama ini sudah cukup

Masalah evaluasi juga tidak luput dari saran yang diucapkan oleh Koes Waluyo selaku pemilik UMKM dengan status WP, yaitu Depot Pecel Madiun di daerah Pucang Jajar Tengah. Beliau mengatakan,

"Sistem ekstensifikasinya sudah bagus, tapi evaluasinya yang lemah. Menurut saya, hal itu perlu untuk dibenahi".

Untuk selanjutnya, peneliti menanyakan hal yang sama tentang saran kegiatan ekstensifikasi PP 46 Tahun 2013 agar pelaksanaan kedepannya menjadi lebih baik kepada Siska, pengelola UMKM fotocopy Pink di daerah Barata Jaya selaku informan UMKM WP. Dia menyarankan,

"Penjangkauan wilayah sosialisasinya harus diratakan".

Berdasarkan jawaban-jawaban tersebut dapat disimpulkan bahwa seluruh pihak informan memiliki pendapat yang sama, bahwa Seksi Ekstensifikasi dan Penyuluhan KPP Pratama Surabaya Gubeng kurang aktif dalam melaksanakan kegiatan ekstensifikasi. Teori penghindaran pasif (Mardiasmo, 2009) sejalan dengan pernyataan Agus Sujarwanto yang mengatakan tidak tahu- 
menahu tentang peraturan perpajakan usaha kecil saat ini. Namun sebaliknya, teori positioning dalam pemasaran (Kotler dan Keller, 2009) bertentangan dengan kegiatan ekstensifikasi PP 46 Tahun 2013 dengan cara penyebaran brosur dan pemasangan banner yang tidak pada tempat target segmentasi.

\subsection{Sikap UMKM Kecamatan Gubeng Kota Surabaya dalam Kegiatan Ekstensifikasi dan Sosialisasi PP 46 Tahun 2013 KPP Pratama Surabaya Gubeng}

Sikap pemilik UMKM dalam menyikapi kegiatan ekstensifikasi PP 46 Tahun 2013 KPP Pratama Surabaya Gubeng merupakan suatu bentuk respon dari persepsi mereka tentang kebutuhan terhadap pajak. Untuk mengetahui lebih jelasnya, peneliti menanyakan kepada salah satu personel Seksi Ekstensifikasi dan Penyuluhan KPP Pratama Surabaya Gubeng, Denok Hanurti, A.Md., “Jenis kendala atau hambatan yang seperti apa ketika melakukan ekstensifikasi?". la mengatakan :

"Kendalanya macam-macam, Dek. Kalau dirinci itu seperti ini, untuk metode ekstensifikasi datang ke tempat UMKM langsung itu kita sering nggak ketemu sama orangnya, atau nggak gitu ya alamat UMKM nggak jelas, jadi kita nyasar gitu. Terus kalau metode ekstensifikasi lewat pemberi kerja itu mereka sering beralasan mereka belum menghitung kumulatif total penjualannya yang di cabang-cabang usahanya".

Untuk meneliti derajat kepercayaan pernyataan petugas KPP Pratama Surabaya Gubeng tersebut, peneliti melanjutkan pertanyaan kepada UMKM "Mengapa UMKM ini tidak didaftarkan menjadi wajib pajak?”. Jawaban pertama meluncur dari Bapak Mizak, pemilik toko retail Syarif Jaya sebagai informan UMKM Non-WP. Beliau menjawab,

"Sengaja tidak mengurus pajak, karena memang toko-toko seperti milik saya ini jarang ada yang membayar pajak".

Peneliti kembali memberikan pertanyaan yang sama kepada Bapak Suyoto, pemilik Toko Wiwin

di Pasar Pucang yang juga tidak mendaftarkan UMKM miliknya menjadi wajib pajak. Beliau mengatakan :

"Mbak kan tau sendiri ya masalah urusan sama pemerintah gitu kan susah. Saya orangnya agak tidak suka yang ribet sama birokrasi. Daripada penjualan toko ini saya bayarkan pajak yang nantinya ada resiko dikorupsi sama pejabat, mending saya sedekahkan sama anak yatim".

Selanjutnya, peneliti melanjutkan pertanyaan kepada Ibu Khadijah, pengelola toko retail non-WP di daerah Jojoran mengenai sikapnya terhadap sosialisasi perpajakan yang dilakukan KPP. la mengatakan,

"Saya tidak bakal datang Mbak, bisa dibilang saya bakalan acuh kepada mereka".

Kemudian, peneliti juga menanyakan hal yang sama kepada Ibu Khadijah, pemilik Toko Jaya Agung yang tidak mendaftarkan tokonya menjadi wajib pajak. Beliau beralasan,

"Pajak ya, saya gak pake bayar-bayar pajak gitu. Ini kan usaha turun-temurun dari orang tua saya mbak, nah sejak dulu sudah ada tradisi mereka gak bayar pajak. Jadi ya saya ngikut." 
Peneliti kembali mengajukan pertanyaan kepada Okky, pemilik Plutos Juice And Coffee tentang alasan beliau tidak mendaftarkan usahanya menjadi wajib pajak. Okky mengatakan,

"Tidak minat bayar dari awal memang. Eman juga kalau untuk mbayar pajak, karna usaha ini memang jadi tulang punggung keluarga saya."

Informan berikutnya, yaitu Azizah selaku pengelola salah satu toko retail di daerah Jojoran. Azizah mengutarakan,

"Gak bakal saya reken, karna saya kan juga gak paham itu untuk apa, seperti apa bentuknya. Jadi ya saya acuhkan saja. Abaikan lah"

Berbeda dengan jawaban Ibu Noerhayati, pemilik Depot Juice di depan Kampus B Unair. Beliau mengatakan tentang sikapnya ketika ada sosialisasi dari petugas ekstensifikasi sebagai berikut :

"Biasa saja sih. Dulu pernah ada gitu orang pajak datang kesini berbicara soal pajak kesana-kemari, saya juga gak paham tentang itu semua. Akhirnya ya cuman saya dengarkan saja. Ujungnya saya bilang 'Nanti dulu ya, saya pikirkan dulu', terus mereka pergi."

Penuturan berbeda dengan jawaban menggantung kedua informan berikut, yakni UMKM Fotokopi Rejeki Jaya dan UMKM Fotokopi Hidayah. UMKM Fotokopi Rejeki Jaya mengatakan,

"Kalau gitu saya cari tau dulu kepentingan dia sosialisasi macam seperti itu buat apa. Kalau cuman untuk sekedar berbagi info sih ya boleh saja, tapi kalau ada dipaksakan buat mbayar pajak, ya maaf aja saya gak mau sama sekali."

Pernyataan serupa dikatakan oleh UMKM Hidayah sebagai berikut :

"Liat dulu, dia mau ngapain sosialisasinya. Kalau misalkan ada niatan dibaliknya ya saya gak hadir, mending saya disini ngurus fotokopian saya."

Berbeda dengan jawaban-jawaban sebelumnya, Pak Supardi sebagai pengelola Fotokopi Barokah mengatakan keterimaannya terhadap kegiatan ekstensifikasi. Seperti yang dituturkan beliau berikut ini,

"Menerima, saya akan membukakan pintu ini lebar-lebar untuk mereka. Soalnya itu kan bisa jadi pengetahuan baru buat saya. Saya sudah lama tidak update masalah pajak."

Untuk memastikan jawaba-jawaban sebelumnya, peneliti mengajukan pertanyaan kembali kepada Bapak Okta "Kendala apa yang dialami KPP Pratama ketika melakukan ekstensifikasi PP 46 Tahun 2013?". Beliau menjawab,

"Masih banyak UMKM yang menghindari pajak dengan berbagai alasan".

Seluruh jawaban dari informan kunci merujuk pada satu garis besar, yakni pemilik UMKM menghindari kegiatan ekstensifikasi dan sosialisasi yang dilakukan oleh KPP Pratama Surabaya Gubeng. Hal ini senada dengan teori penghindaran aktif yang diungkapkan oleh Mardiasmo (2009:12) bahwa masyarakat dengan sengaja tidak membayarkan pajak untuk negara.

\subsection{Pemahaman UMKM Kecamatan Gubeng Kota Surabaya Terhadap Peraturan Perpajakan}

Sebuah pemahaman merupakan kontribusi penting untuk melaksanakan suatu tindakan. Begitu pula yang dialami oleh UMKM di Kecamatan Gubeng Kota Surabaya. Pemahaman UMKM dituntut 
untuk dapat memenuhi kewajiban perpajakan PP 46 Tahun 2013. Namun sayannya, tidak semua UMKM di Kecamatan Gubeng Kota Surabaya menganggap penting keberadaaan pajak.

Hal tersebut senada dengan pernyataan Denok Hanurti, A.Md., mengenai pertanyaan yang dilontarkan peneliti seperti sebelumnya "Kendala apa saja yang terjadi ketika kegiatan ekstensifikasi dan sosialisasi PP 46 Tahun 2013?". la menjawab :

"Paham deh kayaknya. Kita waktu eksten di lapangan gitu selalu bawa surat tugas dari kantor, jadi mereka paham. Kadang dari mereka ada yang langsung daftar. Ada yang alasan berkas dari kita dibawa dulu, nanti biar mereka ngurus sendiri. Tapi selama ini belum ada yang nolak kita sih."

Terdapat wajib pajak yang sadar akan pentingnya pajak, namun mereka tidak mampu mengelola pajak UMKMnya. Setidaknya itulah yang dialami Andre Seftian, pengelola UMKM fotocopy Ramayana di Jalan Dharmawangsa sebagai informan UMKM dengan status wajib pajak. Dia mengungkapkan,

"Jujur saja saya tidak pandai untuk mengurus pajak, tapi fotocopy ini sudah terdaftar menjadi wajib pajak Iho. Jangan salah. Jadi untuk pengurusan pajaknya gitu saya serahkan sama konsultan pajak".

Pemahaman yang kurang mengenai pajak penghasilan dilontarkan oleh Andi, selaku pengelola Toko 56 Jaya. Dia mengatakan,

"Toko ini baru saya dirikan setaun belakangan, sejak saya keluar dari perusahaan tempat saya kerja. Dan saya juga belum paham mengenai pajak badan usaha, saya mudengnya untuk pajak orang pribadi."

Begitu juga dengan Pak Supardi, pemilik usaha Fotokopi Barokah. Beliau mengatakan,

"Saya belum tahu batasan kategori yang untuk jadi wajib pajak itu batasan omzetnya berapa, kategorinya apa aja. Memangnya sekarang sudah ada pajak untuk usaha kecil ya?"

Selanjutnya, peneliti menanyakan hal yang sama tentang pemahaman pajak usaha kecil kepada Azizah, pengelola Toko Mukirman. Dia menjawab,

"Gak paham buat pajak-pajak gitu. Saya cuman tau pajak itu ya cuman PBB. Selain pajak itu saya gak tau".

Peneliti kembali mengalihkan fokus penelitian kepada UMKM dengan status wajib pajak. Peneliti menanyakan alasan ketidakpahaman mereka terhadap peraturan perpajakan. Jawaban pertama dilontarkan oleh Siska, pegawai Pink Fotocopy. Dia menjawab,

"Gak tahu. Saya cuman Iulusan SMA. Gak tau apa-apa soal pajak gitu. Semua urusan perpajakan fotokopian ini saya diserahkan sama orang lain, bukan pegawai, tapi kayak orang biro jasa pajak gitu."

Kurang detailnya aturan pajak menjadi alasan Pemilik Depot Madiun. Beliau mengungkapkan,

"Setahu saya ada peraturan baru tentang pajak penghasilan gitu, tapi gak tau gimana detail aturannya."

Untuk menguji pernyataan-pernyataan tersebut, peneliti melakukan pertanyaan lanjutan kepada praktisi akademis Bapak Okta mengenai pemahaman UMKM tentang pajak. Beliau mengungkapkan, 
"Menurut saya, satu-satunya kendala kegiatan ekstensifikasi dan sosialisasi peraturan pajak itu hanya pemahaman dari calon wajib pajak yang kurang. Kesadaran mereka tentang keberadaan pajak benar-benar sangat kurang."

Berdasarkan jawaban-jawaban tersebut, peneliti mengambil sebuah garis besar bahwa pemahaman UMKM Kecamatan Gubeng Kota Surabaya masih bisa dikatakan kurang. Ketiga informan kunci, seksi ekstensifikasi dan penyuluhan KPP Pratama Surabaya Gubeng, pemilik UMKM, dan praktisi akademis sependapat mengenai hal itu.

\section{Simpulan}

Dapat diambil beberapa simpulan bahwa kendala penerapan ekstensifikasi wajib pajak UMKM Kecamatan Gubeng Kota Surabaya sesudah pemberlakuan PP 46 Tahun 2013 adalah sebagai berikut:

1) Pihak KPP Pratama Surabaya Gubeng cenderung kurang aktif dalam melakukan ekstensifikasi PP 46 Tahun 2013.

2) Pemilik UMKM di Kecamatan Gubeng Kota Surabaya yang tidak terdaftar menjadi wajib pajak cenderung dengan sengaja menghindari kegiatan ekstensifikasi dan sosialisasi yang dilakukan KPP Pratama Surabaya Gubeng.

3) Kurangnya pemahaman pemilik UMKM di Kecamatan Gubeng Kota Surabaya yang berstatus wajib pajak tentang seluk-beluk perpajakan.

\section{Daftar Pustaka}

Badan Pusat Statistik. 2014. Produk Domestik Regional Bruto Atas Dasar Harga Berlaku Menurut Provinsi, 2000-2013 (Miliar Rupiah). https://www.bps.go.id/linkTabelStatis/view/id/1622 (Diakses 13 Mei 2015).

Chandler, R. C., dan J. C. Plano. 1988. The Public Administration Dictionary. John Wiley \& Sons.

http://www.smartbisnis.co.id/direktoriukm/cari?city=244\&Dir_sort=district.desc\&Dir_page=1425

(Diakses 16 Maret 2015).

Kharisma, R. 2014. Pengaruh Pelaksanaan Peraturan Pemerintah Republik Indonesia Nomor 46 Tahun 2013 Tentang Pajak Penghasilan Terhadap Kelangsungan Usaha Mikro Kecil dan Menengah (UMKM). Skripsi. Jember: PPs Universitas Negeri Jember.

Kuncahyo, A. A. 2013. Upaya Meningkatkan Kesadaran Pemilik Usaha Kecil Menengah Dalam Memenuhi Kewajiban Perpajakan. Jurnal Akuntansi dan Bisnis 1 (1).

Kotler, P., dan K. L. Keller. 2009. Manajemen Pemasaran. Edisi 3 Jilid 2. Jakarta: Penerbit Erlangga. Mardiasmo. 2009. Perpajakan. Edisi Revisi 2009. Yogyakarta: Penerbit Andi.

Moleong, L. J. 2014. Metode Penelitian Kualitatif Edisi Revisi. Bandung: PT. Remaja Rosdakarya.

Peptasari, A. L. 2015. Analisis Penerapan Peraturan Pemerintah Nomor 46 Tahun 2013 Terhadap Tingkat Pertumbuhan Wajib Pajak Dan Penerimaan PPh Pasal 4 Ayat (2) (Studi Kasus Pada Kantor Pelayanan Pajak Pratama Surakarta). Skripsi. Surakarta: Universitas Muhammadiyah Surakarta.

Purbaningrum, S. D. 2014. Kepatuhan Wajib Pajak Terhadap Penerapan Peraturan Pemerintah Nomor 46 Tahun 2013 Pada KPP Pratama Blitar. Jurnal IImiah Mahasiswa FEB Universitas Brawijaya 3(2).

Republik Indonesia. 2013. Peraturan Pemerintah Nomor 46 Tahun 2013 tentang Pajak Penghasilan Atas Penghasilan Dari Usaha Yang Diterima Atau Diperoleh Wajib Pajak Yang Memiliki Peredaran Bruto Tertentu. Jakarta.

Republik Indonesia. 2013. Peraturan Direktorat Jenderal Pajak Nomor PER-35/PJ/2013 Tentang Tata Cara Ekstensifikasi. Jakarta. 
Resyniar, G., dan D. Puspitasari. 2014. Persepsi Pelaku Usaha Mikro Kecil Menengah (UMKM) Terhadap Penerapan PP.46 Tahun 2013. Jurnal IImiah Mahasiswa FEB Universitas Brawijaya 2 (2).

Sukmawati, W. 2014. Efektifitas Pelaksanaan Ekstensifikasi Wajib Pajak Melalui Pemberian Nomor Pokok Wajib Pajak (NPWP) Dalam Rangka Meningkatkan Penerimaan Pajak Penghasilan (Studi Pada Kantor Pelayanan Pajak Pratama Malang Utara). Jurnal Mahasiswa Perpajakan Universitas Brawijaya.

Soemitro, R. 2000. Dasar-dasar Hukum Pajak dan Pajak Pendapatan. Jakarta: Erlangga.

Suandy, E. 2011. Hukum Pajak. Jakarta: Salemba Empat. 